\title{
PENGARUH KESELAMATAN DAN KESEHATAN KERJA TERHADAP PRODUKTIVITAS KERJA KARYAWAN DI PABRIK ROTI BUNGA MAWAR KOTA LUBUKLINGGAU
}

\author{
Suwarno \\ (suwarno221273@gmail.com) \\ Ronal Aprianto \\ (ronal.gbs@gmail.com) \\ Weni Susanti \\ (wenisusanti50@gmail.com)
}

\begin{abstract}
ABSTRAK
Penelitian ini berjudul Pengaruh Keselamatan dan Kesehatan Kerja terhadap Produktivitas Kerja Karyawan di Pabrik Roti Bunga Mawar Kota Lubuklinggau, dengan tujuan untuk mengetahui pengaruh Keselamatan dan Kesehatan Kerja terhadap Produktivitas Kerja Karyawan di Pabrik Roti Bunga Mawar Kota Lubuklinggau, jumlah responden dalam penelitian ini sebanyak 32 orang dan menggunakan instrumen penelitian berupa kuesioner yang hasil datanya diolah menggunakan bantuan program SPSS 17 dengan hasil regresi liner berganda $Y=16.986+0,118 X_{1}+0,492 X_{2}$, kemudian hasil dari uji koefisien determinasi $\left(R^{2}\right)$ sebesar $49,5 \%$ sementara sisanya sebesar 50,5\% dipengaruhi oleh variabel lain yang tidak masuk dalam penelitian ini, adapun hasil dari uji $F$ didapatkan nilai $F_{\text {hitung }}=14,250>F_{\text {tabel }}=3,33$ sehingga Ho ditolak dan terima Ha yang artinya terdapat pengaruh yang signifikan secara simultan (bersama-sama) antara keselamatan dan kesehatan kerja terhadap produktivitas kerja.
\end{abstract}

Kata Kunci : Keselamatan, Kesehatan, Produktivitas Kerja

\begin{abstract}
This research is entitled Occupational Safety and Health to Employee Productivity at Lubuklinggau City Mawar Roti Factory, with the aim of knowing Occupational Safety and Health for Employee Productivity at Lubuklinggau City Roti Bunga Mawar Factory, 32 respondents in this study and using instruments The study consisted of questionnaires that produced data processed using the SPSS 17 assistance program with the results of multiple regression $\mathrm{Y}=16,986+0.118 \mathrm{X} 1+0.492 \mathrm{X} 2$, then starting from the test the coefficient of determination (R2) of $49.5 \%$ while remaining at $50.5 \%$ Related with other variables not included in this study, as for the results of the research $\mathrm{F}$ obtained Fcount $=14,250>$ Ftable $=3.33$ so that Ho is rejected and received Ha which needs to be discussed simultaneously simultaneously (together) between occupational safety and health towards work productivity.
\end{abstract}

Keywords: Safety, Health, Work Productivity 


\section{PENDAHULUAN}

Sumber daya manusia memiliki peranan penting bagi keberhasilan suatu organisasi atau perusahaan, karena manusia merupakan aset hidup yang perlu dipelihara dan dikembangkan. Oleh karena itu karyawan harus mendapatkan perhatian yang khusus dari perusahaan. Hal ini dimaksudkan agar sumber daya manusia yang dimiliki perusahaan mampu memberikan kontribusi yang optimal dalam upaya pencapaian tujuan organisasi.

Dalam pengelolaan sumber daya manusia inilah diperlukan manajemen yang mampu mengelola sumber daya secara sistematis, terencana, dan efisien. Salah satu hal yang harus menjadi perhatian utama bagi manajer sumber daya manusia ialah sistem Keselamatan dan Kesehatan Kerja (K3). Dikarenakan apabila tingkat keselamatan kerja tinggi, maka kecelakaan yang menyebabkan sakit, cacat, dan kematian dapat ditekan sekecil mungkin. Kemudian, apabila keselamatan kerja rendah, maka hal tersebut akan berpengaruh buruk terhadap kesehatan sehingga berakibat pada produktivitas yang menurun.

Produktivitas sumber daya manusia ditentukan oleh sejauh mana sistem yang ada di perusahaan mampu menunjang dan memuaskan keinginan seluruh pihak. Apabila suatu perusahaan peduli dengan keberadaan dan kesejahteraan karyawan, maka karyawan akan meningkatkan produktivitas kerjanya terhadap perusahaan. Salah satu faktor yang mempengaruhi produktivitas karyawan adalah keselamatan dan kesehatan kerja (K3).

Keselamatan dan kesehatan kerja merupakan Hak Asasi Manusia (HAM). Untuk itu, kesadaran mengenai pentingnya K3 harus selalu digugah, diingatkan, serta dibudidayakan di kalangan para pekerja. Pemahaman dan pelaksanaan K3 diperusahaan sangat diperlukan, terutama dalam perbaikan syarat-syarat kerja. Hal ini, berkaitan dengan masalah perlindungan tenaga kerja terhadap kecelakaan kerja, guna meminimalisir kemungkinan terjadinya kecelakaan kerja, perlu pemahaman dan pelaksanaan K3 secara baik dan benar.

Berdasarkan latar belakang di atas, maka peneliti tertarik untuk melakukan penelitian dengan judul : Pengaruh Keselamatan dan Kesehatan Kerja terhadap Produktivitas Kerja Karyawan di Pabrik Roti Bunga Mawar Kota Lubuklinggau.

\section{Rumusan Masalah}

Berdasarkan latar berlakang di atas, maka peneliti merumuskan permasalahan: adakah pengaruh keselamatan dan kesehatan kerja terhadap produktivitas kerja karyawan di pabrik Roti Bunga Mawar Kota Lubuklinggau?

\section{Tujuan Penelitian}

Berdasarkan variabel yang diangkat sebagai fenomena permasalahan yang ada di pabrik Roti Bunga Mawar, tujuan dari penelitian ini selain untuk mengetahui pengaruh keselamatan dan kesehatan kerja terhadap produktivitas kerja karyawan di pabrik Roti Bunga Mawar Kota Lubuklinggau. 


\section{Manfaat Penelitian}

Adapun manfaat dari penelitian ini adalah sebagai berikut:

a. Sebagai bahan pertimbangan dan sumber informasi bagi pemilik pabrik Roti Bunga Mawar mengenai Keselamatan dan Kesehatan Kerja (K3) guna meningkatkan produktivitas kerja karyawan di pabrik Roti Bunga Mawar Kota Lubuklinggau.

b. Sebagai bahan referensi dan informasi dalam manajemen sumber daya manusia khususnya mengenai pengaruhKeselamatan dan Kesehatan Kerja (K3) terhadap produktivitas kerja karyawan.

\section{Tinjauan Pustaka}

1. Landasan Teori

\section{a. Pengertian Produktivitas}

Produktivitas adalah rasio dari hasil kerja dengan waktu yang dibutuhkan untuk menghasilkan produk dari seorang tenaga kerja (Sutrisno, 2016:102). Sedangkan, menurut Muchdarsyah Sinungan (dalam Nurjaman, 2014:220) mendefinisikan produktivitas sebagai perbandingan antara totalitas pengeluaran pada waktu tertentu dibagi totalitas masukan selama periode tertentu.

\section{b. Pengertian Keselamatan dan Kesehatan Kerja}

Menurut Nurjaman (2014:290) keselamatan kerja adalah terhindarnya hal-hal yang menyebabkan terganggunya pegawai dari segi fisik dan mental pada saat melaksanakan pekerjaan dan setelah menunaikan tugas dan kewajiban yang diberikan oleh perusahaan. Menurut Mangkunegara (2013:161) kesehatan kerja menunjukkan pada kondisi yang bebas dari gangguan fisik, mental, emosi atau rasa sakit yang disebabkan oleh lingkungan kerja. Risiko kesehatan merupakan faktor-faktor dalam lingkungan kerja yang bekerja melebihi periode waktu yang ditentukan, lingkungan yang dapat membuat stress emosi atau gangguan fisik.

\section{Kerangka Pemikiran}

Kerangka pemikiran dalam penelitian ini dapat digambarkan dibawah ini :

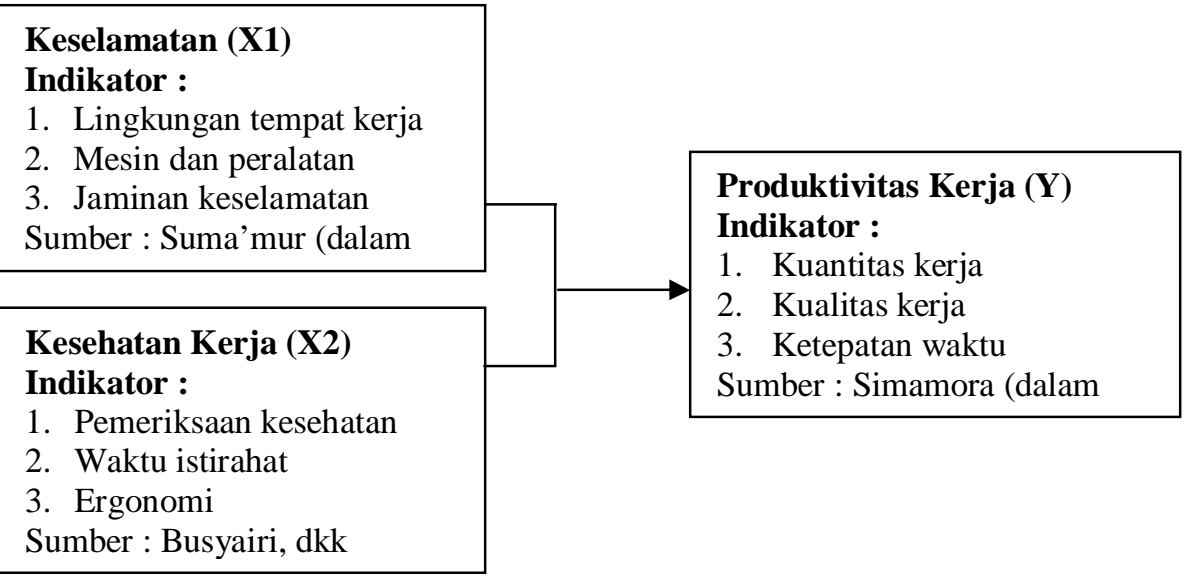




\section{Hipotesis}

Hipotesis dalam penelitian ini yaitu, terdapat pengaruh keselamatandan kesehatan kerja terhadap produktivitas kerja karyawan di pabrik Roti Bunga Mawar Kota Lubuklinggau.

\section{Metodologi Penelitian}

Penelitian ini dilakukan di pabrik Roti Bunga Mawar yang terletak di Jalan Nakula RT.004 Kelurahan Marga Mulya Kecamatan Lubuklinggau Selatan II Kota Lubuklinggau Provinsi Sumatera Selatan.

Populasi dalam penelitian ini adalah para karyawan pabrik Roti Bunga Mawar Kota Lubuklinggau yang berjumlah 32 karyawan. Sampel dalam penelitian ini adalah semua karyawan tetap di pabrik Roti Bunga Mawar Kota Lubuklinggau dengan menggunakan sampel jenuh atau sensus yang berjumlah 32 orang.

Pengujiannya dilakukan secara statistik, yang dilakukan dengan menggunakan bantuan program IBM Stastitical for Product and Service Solution (SPSS). Dengan menggunakan uji regresi, koefisien determinasi dan uji $\mathrm{F}$ (simultan).

\section{Hasil Penelitian Dan Pembahasan}

\section{Hasil Uji Asumsi Klasik}

\section{a. Uji Normalitas}

Hasil dari uji normalitas dengan menggunakan uji kolmogorov-smirnovdapat dilihat pada tabel di bawah ini :

\section{Tabel 1}

\section{Hasil Uji Normalitas}

\begin{tabular}{lcrrr}
\hline & & $\begin{array}{c}\text { Keselamatan Kerja } \\
\left(\mathbf{X}_{\mathbf{1}}\right)\end{array}$ & $\begin{array}{r}\text { Kesehatan Kerja } \\
\left(\mathbf{X}_{\mathbf{2}}\right)\end{array}$ & $\begin{array}{c}\text { Produktivitas } \\
\text { Kerja (Y) }\end{array}$ \\
\hline $\mathrm{N}$ & & 32 & 32 & 32 \\
Normal parameters & & 40.72 & 41.91 & 42.41 \\
& & 3.245 & 3.745 & 2.993 \\
Most Extreme Differences & Absolute & .150 & .195 & .181 \\
& Positive & .150 & .195 & .181 \\
& Negative & -.073 & -.095 & -.117 \\
Kolmogorov-Smirnov Z & & .849 & 1.101 & 1.023 \\
Asymp. Sig. (2-tailed) & & .466 & .177 & .247 \\
\hline
\end{tabular}

\section{Sumber : Hasil Olah Data 2018}

Dari tabel di atas menunjukkan bahwa Asymp. Sig. (2-tailed) Variabel Keselamatan Kerja $\left(\mathrm{X}_{1}\right)$ nilainya sebesar 0,466 lebih besar dari 0,05, maka disimpulkan bahwa Keselamatan Kerja $\left(\mathrm{X}_{1}\right)$ berdistribusi normal. Untuk Variabel Kesehatan Kerja $\left(\mathrm{X}_{2}\right)$ nilainya sebesar 0,177 lebih besar dari 0,05, maka disimpulkan bahwa Kesehatan Kerja $\left(\mathrm{X}_{2}\right)$ berdistribusi normal. Kemudian untuk Variabel Produktivitas Kerja (Y) nilainya sebesar 0,247 lebih besar dari 0,05, maka disimpulkan bahwa Produktivitas Kerja (Y) berdistribusi normal. 


\section{b. Uji Linieritas}

Hasil dari uji linieritas dapat dilihat pada tabel di bawah ini :

Tabel 2

ANOVA Table

\begin{tabular}{|c|c|c|c|c|c|}
\hline & $\begin{array}{c}\text { Sum of } \\
\text { Squares }\end{array}$ & df & Mean Square & $\mathrm{F}$ & Sig. \\
\hline Produktivitas kerja Between groups (Combined) & 168.452 & 12 & 14.038 & 2.441 & .040 \\
\hline *Keselamatan kerja Linearity & 75.172 & 1 & 75.172 & 13.071 & .002 \\
\hline \\
\hline From & 93.280 & 11 & 8.480 & 1.475 & .220 \\
\hline Within groups & 109.267 & 19 & 5.751 & & \\
\hline Total & 277.719 & 31 & & & \\
\hline
\end{tabular}

Sumber : Hasil Olah Data 2018

Dari tabel di atas menunjukkan bahwa hasil signifikansi variabel keselamatan kerja (X1) terhadap produktivitas kerja (Y) pada kolom Deviation From Linearity diperoleh nilai $F$ sebesar 1.475 dengan nilai Sig. 0,220. Karena nilai Sig. lebih besar daripada 0,05, maka dengan demikian dapat disimpulkan bahwa uji linearitas terpenuhi.

Tabel 3

ANOVA Table

\begin{tabular}{|c|c|c|c|c|c|c|}
\hline & & $\begin{array}{c}\text { Sum of } \\
\text { Squares }\end{array}$ & df & Mean Square & $\mathrm{F}$ & Sig. \\
\hline Produktivitas kerja & Between groups (Combined) & 202.919 & 13 & 15.609 & 3.756 & .005 \\
\hline *Kesehatan kerja & Linearity & 134.961 & 1 & 134.961 & 32.447 & .000 \\
\hline \multicolumn{7}{|l|}{ Deviation } \\
\hline From & & 67.958 & 12 & 5.663 & 1.363 & .268 \\
\hline & Within groups & 74.800 & 18 & 4.156 & & \\
\hline & Total & 277.719 & 31 & & & \\
\hline
\end{tabular}

Dari tabel di atas menunjukkan bahwa hasil signifikansi variabel kesehatan kerja (X2) terhadap produktivitas kerja (Y) pada kolom Deviation From Linearity diperoleh nilai F sebesar 1.363 dengan nilai Sig. 0,268. Karena nilai Sig. lebih besar daripada 0,05, maka dengan demikian dapat disimpulkan bahwa uji linearitas terpenuhi.

\section{Hasil Uji Hipotesis}

\section{a. Hasil Regresi Linier Berganda}

\section{Tabel 4}

Hasil Regresi Linier Berganda

\begin{tabular}{|c|c|c|c|}
\hline \multirow[b]{2}{*}{ Model } & \multicolumn{2}{|c|}{ Unstandardized Coefficient } & \multirow{2}{*}{$\begin{array}{c}\text { Standardized Coefficient } \\
\text { Beta } \\
\end{array}$} \\
\hline & B & Std. Error & \\
\hline $\begin{array}{ll}1 \text { (Constant) } \\
\end{array}$ & 16.986 & 5.230 & \\
\hline Keselamatan Kerja (X1) & .118 & .158 & .128 \\
\hline Kesehatan Kerja (X2) & .492 & .137 & 616 \\
\hline
\end{tabular}

Dari tabel di atas menunjukkan bahwa model persamaan regresi berganda untuk memperkirakan produktivitas kerja yang dipengaruhi oleh keselamatan dan kesehatan kerja adalah : $\mathrm{Y}=16.986+0,118 \mathrm{X}_{1}+0,492 \mathrm{X}_{2}$. 


\section{b. Hasil Koefisien Determinasi $\left(\mathbf{R}^{2}\right)$}

\section{Tabel 5}

Hasil Koefisien Determinasi $\left(\mathbf{R}^{2}\right)$

\begin{tabular}{lcccc}
\hline Model & R & R Square & Adjusted R Square & Std. Error of the \\
Estimate & .461 & 2.198 \\
\hline
\end{tabular}

Sumber : Hasil Olah Data 2018

Hasil korelasi (R) yang secara simultan (bersama-sama) antara variabel keselamatan $\left(\mathrm{X}_{1}\right)$ dan kesehatan kerja $\left(\mathrm{X}_{2}\right)$ terhadap produktivitas kerja $(\mathrm{Y})$ diperoleh nilai sebesar $r=0,704$. Kemudian dihitung dengan rumus : $K P=\left(R_{\mathrm{X} 1 . \mathrm{X} 2 . \mathrm{Y}}\right)^{2} \times 100 \%=$ $(0,704)^{2} \times 100 \%=49,5 \%$.

Kontribusi yang diberikan oleh kedua variabel ini terhadap variabel (Y) adalah sebesar $49,5 \%$. Sementara sisanya sebesar $50,5 \%$ dipengaruhi oleh variabel lain yang tidak masuk dalam penelitian ini.

\section{c. Hasil Uji F (Simultan)}

Tabel 6

Hasil Uji F (Simultan)

\begin{tabular}{lccccc}
\hline \multicolumn{1}{c}{ Model } & Sum Of Squares & df & Mean Square & F & Sig. \\
\hline Reggresion & 137.654 & 2 & 68.827 & 14.250 & $.000^{(a)}$ \\
Residual & 140.065 & 29 & 4.830 & & \\
Total & 277.719 & 31 & & & \\
\hline Sumber & & & & & \\
\hline
\end{tabular}

Dari tabel di atas, diperoleh nilai $F_{\text {hitung }}=14,250>F_{\text {tabel }}=3,33$ sehingga Ho ditolak dan terima Ha. Yang artinya terdapat pengaruh yang signifikan secara simultan (bersama-sama) antara keselamatan dan kesehatan kerja terhadap produktivitas kerja.

\section{Pembahasan}

Hasil analisis regresi linier berganda, diperoleh persamaan $Y=16,986+0,118 \mathrm{X}_{1}$ $+0,492 \mathrm{X}_{2}$. Dengan penjelasan $\mathrm{Y}$ adalah produktivitas kerja, $\mathrm{X}_{1}$ adalah keselamatan kerja, dan $\mathrm{X}_{2}$ adalah kesehatan kerja. Dari persamaan di atas, dapat dianalisis bahwa Produktivitas kerja, jika tanpa adanya keselamatan dan kesehatan kerja $\left(X_{1}\right.$ dan $\left.X_{2}=0\right)$, maka produktivitas kerja hanya 16,986. Sedangkan Koefisien regresi berganda sebesar 0,118 dan 0,492 mengindikasikan bahwa besaran penambahan tingkat produktivitas kerja setiap pertambahan jawaban responden untuk variabel keselamatan dan kesehatan kerja.

Hasil korelasi (R) yang secara simultan (bersama-sama) antara variabel keselamatan $\left(\mathrm{X}_{1}\right)$ dan kesehatan kerja $\left(\mathrm{X}_{2}\right)$ terhadap produktivitas kerja $(\mathrm{Y})$ diperoleh nilai sebesar $\mathrm{r}=0,704 . \mathrm{KP}=\left(\mathrm{R}_{\mathrm{X} 1 \mathrm{X} 2 \mathrm{Y} . \mathrm{Y}}\right)^{2} \times 100 \%=(0,704)^{2} \times 100 \%=$ $49,5 \%$. Maka kontribusi yang diberikan oleh kedua variabel ini terhadap variabel (Y) adalah sebesar 49,5\%. Sementara sisanya sebesar 50,5\% dipengaruhi oleh variabel lain yang tidak masuk dalam penelitian ini.

Dengan menggunakan tingkat keyakinan $\alpha=0,05$ diperoleh nilai $F_{\text {hitung }}=14,250>$ $\mathrm{F}_{\text {tabel }}=3,33$ sehingga Ho ditolak dan terima Ha. Yang artinya terdapat pengaruh yang signifikan secara simultan (bersama-sama) antara keselamatan dan kesehatan kerja terhadap produktivitas kerja. 
Hasil penelitian yang telah peneliti lakukan, menemukan bahwa keselamatan dan kesehatan kerja mempunyai pengaruh yang signifikan terhadap produktivitas kerja karyawan di pabrik Roti Bunga Mawar Kota Lubuklinggau. Sehingga dapat disimpulkan bahwa penelitian ini sejalan dengan penelitian yang sebagaimana dilakukan oleh peneliti sebelumnya.

\section{SIMPULAN DAN SARAN}

\section{Kesimpulan}

Berdasarkan rumusan masalah yaitu, adakah pengaruh keselamatan dan kesehatan kerja terhadap produktivitas kerja karyawan di pabrik Roti Bunga Mawar Kota Lubuklinggau?. Peneliti menyimpulkan, bahwa terdapat pengaruh yang positif dan signifikan secara bersama-sama antara keselamatan dan kesehatan kerja terhadap produktivitas kerja karyawan di pabrik Roti Bunga Mawar Kota Lubuklinggau.

\section{Saran}

Dari hasil penelitian ini diberikan beberapa saran, antara lain :

a. Keselamatan Kerja

Pelatihan serta pemeliharaan dari peralatan dan mesin produksi haruslah diterapkan dan diperhatikan, demi meminimalisir tingkat kecelakaan kerja yang berujung pada kerugian, baik dari pihak karyawan maupun pihak pemilik perusahaan/industri itu sendiri.

b. Kesehatan Kerja

Hidup sehat sehat itu mudah, cukup dimulai dari memperhatikan pola hidup diri sendiri atau istilahnya Personal Hygiene. Setelah itu barulah dilanjutkan ketahap pemeliharaan lingkungan, baik lingkungan kerja maupun lingkungan keluarga.

c. Produktivitas Kerja

Dalam bidang industri, manajemen dalam penetapan posisi kerja serta penetapan jumlah target produksi haruslah diperhatikan secara khusus. Hal ini bertujuan untuk meningkatkanefisiensi penggunaan sumber daya serta efektivitas pencapaian tujuan.

\section{DAFTAR PUSTAKA}

Arikunto, Suharsimi. 2014. Prosedur Penelitian Suatu Pendekatan Praktik. Cetakan ke XV.Jakarta : Rineka Cipta.

Bella Gloria Ukhisia, dkk. 2013. Analisis Pengaruh Keselamatan Dan Kesehatan Kerja Terhadap Produktivitas Karyawan Dengan Metode Partial Least Squares.Vol.14, No.2. Universitas Brawijaya. 
Diegyvano.wordpress.com. 2012. Variabel Penelitian. (Online). (https:// diegyvano.wordpress.com/ 2012/12/16/ variabel-penelitian/. Diakses23 Februari 2018).

Gurupendidikan.co.id. 2017. Produktivitas. (Online). (http://www. gurupendidikan. co.id/produktivitas-pengertian-menurut-para-ahli-tujuan-manfaat-faktor-yangmempengaruhi/Di akses 23 Februari 2018).

Hadi Prayitno, dkk. 2015. The Effect of Occupational Safety and Health on Work Productivity of Field Workers of Access Network Maintenance at Pt. Telkom Kandatel Jember.Vol.22, No.17. IJSBAR.

Hermanpu.blogspot.co.id. 2015. Prinsip Keselamatan Kerja. (Online) (http://hermanpu.blogspot.co.id/2015/05/prinsip-keselamatan-kerja.html?m=1Di akses 23 Februari 2018).

Junaidi-itp.blogspot.in. 2012.Produktivitas Kerja (Online). (http://junaidiitp.blogspot.in/2012/12/produktivitas-kerja.html?m=1Di akses 23 Februari 2018).

Mangkunegara, Anwar Prabu. 2013.Manajemen Sumber Daya Manusia Perusahaa. Cetakan ke XI. Bandung : Remaja Rosdakarya Offset.

Muhammad Busyairi, dkk. 2014. Pengaruh Keselamatan Kerja dan Kesehatan Kerja terhadap Produktivitas Kerja Karyawan. Vol.13, No.2. Universitas Mulawarman.

Nurjaman, Kadar. 2014. Manajemen Personalia. Cetakan ke I. Bandung: CV Pustaka Setia.

Riadi, Edi. 2016. Statistika Penelitian (Analisis Manual dan IBM SPSS). Edisi ke I. Yogyakarta: CV Andi Offset.

Siregar, Syofian. 2017. Statistika Parametrik untuk Penelitian Kuantitatif Dilengkapi dengan Perhitungan Manual dan Aplikasi SPSS Versi 17.Cetakan ke IV. Jakarta: PT Bumi Aksara.

Soedirman dan Suma'mur PK. 2014. Kesehatan Kerja Dalam Prespektif Hiperkes \& Keselamatan Kerja.Jakarta: Erlangga.

Sucipto, Cecep Dani. 2014. Keselamatan Dan Kesehatan Kerja.Cetakan ke IYogyakarta: Gosyen Publising.

Sugiyono. 2017. Metode Penelitian Administrasi.Cetakan ke XXIV.Bandung: Alfabeta.

Sutrisno, Edy. 2016. Manajemen Sumber Daya Manusia. Cetakan ke VIII. Jakarta : Prenadamedia Group.

Wibowo, Endro dan Hardi Utomo. 2016.Pengaruh Keselamatan Kerjadan Kesehatan Kerja Terhadap Kinerja Dengan Kepuasan Kerja Sebagai Variabel Intervening (Studi Kasus pada Karyawan Bagian Produksi Unit Serbuk EffervescentPT Sido Muncul Semarang). Vol.9, No.17. STIE AMA Salatiga.

Widayana, I Gede dan I Gede Wiratmaja. 2014. Kesehatan dan Keselamatan Kerja.Cetakan ke I.Yogyakarta: Graha Ilmu.

Wikipedia.org. 2017. Produktivitas. (Online). (https://id.m.wikipedia.org/ wiki/produktivitas. Diakses23 Februari 2018). 